\title{
Squamous Cell Carcinoma in a Hallikar Bullock
}

\author{
Ashna S*, I.S. Sajitha, S.S. Devi, Sairam R, Dhanush Krishna B. and \\ Mammen J Abraham
}

Department of Veterinary Pathology, College of Veterinary and Animal Sciences, Mannuthy, Thrissur, Kerala, India

*Corresponding author email: ashnasulaiman19@gmail.com; Ph.+91-9847295955

Journal of Livestock Science (ISSN online 2277-6214) 10: 29-31

Received on 23/3/2019; Accepted on 24/5/2019

doi. 10.33259/JLivestSci.2019.29-31

\begin{abstract}
A 2 year old Hallikar bullock was presented to Department of Veterinary Surgery and Radiology, College of Veterinary and Animal Sciences, Mannuthy with a history of bleeding growth around the base of left horn. Tissue samples from the growth were collected for histopathology. Grossly, the growth had a cauliflower like appearance with areas of ulceration and hemorrhage. On detailed histopathological examination, the dermis was seen invaded by neoplastic squamous epithelial cells. The cells were seen differentiated to form irregular islands of squamous epithelium. Islands of neoplastic squamous cells were surrounded by proliferating fibroblast and collagen. Hyper keratinization of the dermis with keratin pearl could also be observed. Histopathological features confirmed the case as squamous cell carcinoma.
\end{abstract}

Keywords: Keratin pearl; Squamous cell carcinoma; Hallikar bullock; Hyperkeratinisation; Horn cancer. 


\section{Introduction}

Squamous cell carcinoma is the second most common form of skin cancer. It is a malignant tumor of epidermal cells. These tumors grow slowly, but are aggressive in nature. However, they do not metastasize to the regional lymph nodes. Among all tumors of cattle, horn cancer is considered to be the most common one. They are painful and fill the horn core and may infiltrate to the frontal sinuses. The incidence of squamous cell carcinoma has been reported to be $80 \%$ in cattle and 3\% in buffalo (Somvanshi, 1991). Bullocks are more susceptible than cows. Horn cancer is more common in 5-10 year age group with more prevalence in long horned one. Hallikar breed is considered as the premier draught breed of India. They have a peculiar lyre shaped horn. They are mainly distributed in Mysore, Mandya, Bangalore, Kolar, Hassan and Chitradurga in Karnataka (Nivsarkar et al., 2000). Tumor appears as a cauliflower like growth with ulceration and bleeding from the surfaces. Most common clinical signs are frequent head shaking, tilting to the affected area, increased nasal discharge on the affected side (Joshi et al., 2009). Present communication describes a case report of horn cancer in a Hallikar bullock with age less than 5 years.

\section{Materials and methods}

A 2 year old Hallikar breed bullock was presented to Department of Veterinary Surgery and Radiology with a history of bleeding growth around the base of the horn since last four months. On clinical examination, the mass appeared to be hard and cauliflower shaped with some hemorrhagic spots. For histopathological examination tissue samples were collected and fixed in $10 \%$ neutral buffered formalin. After fixation, tissue samples were processed and stained by Hematoxylin and Eosin (H\&E) standard protocol (Luna 1968). Slides were viewed in x10, x20 and x40 using light microscope.

\section{Result and Discussion}

Histopathological examination revealed well differentiated invasive type squamous cell carcinoma infiltrating into the basal layer and dermis with hyper keratinization. Anastomosing cords and nets composed of polyhedral shaped cells with prickle borders, glassy eosinophilic cytoplasm and enlarged nuclei were present (Fig 1). These neoplastic squamous epithelial cells that had arisen from the basal cells of the epidermis, differentiated to form irregular islands of squamous epithelium and got surrounded by fibroblasts and collagen (desmoplasia) (Vara Prasad et al., 2016) (Fig 1).

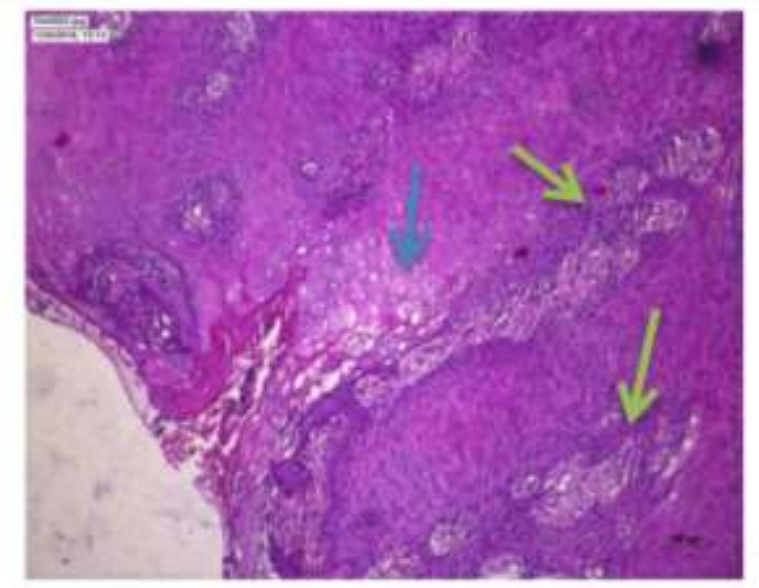

Fig 1 Hyperkeratinisation of the dermis with irregular islands of squamous cells (green arrow), polyhedral cells with glassy eosinophilic cytoplasm with enlarged nuclei (blue arrow). H\&E $(100 x)$

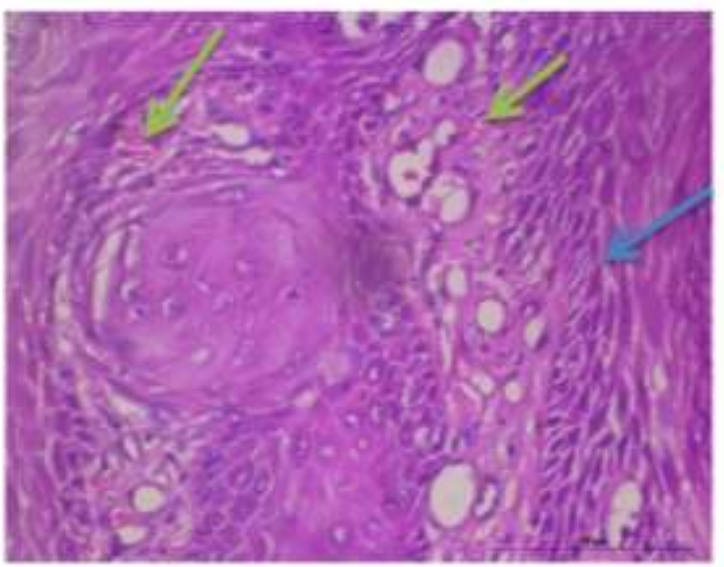

Fig 2 Neo-vascularization within the islands of neoplastic cells (Green arrow). Intercellular bridging was also observed (Blue arrow) H\&E (400x). 


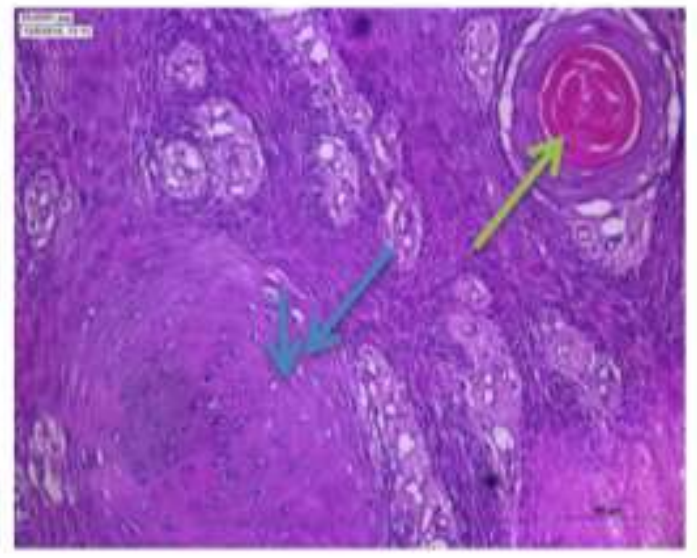

Fig: 3 Epithelial pearl or cell nest appear as pink color (Green arrow), Keratinized cells showed small hyper chromatic nuclei (Blue arrow). $H \& E(200 x)$

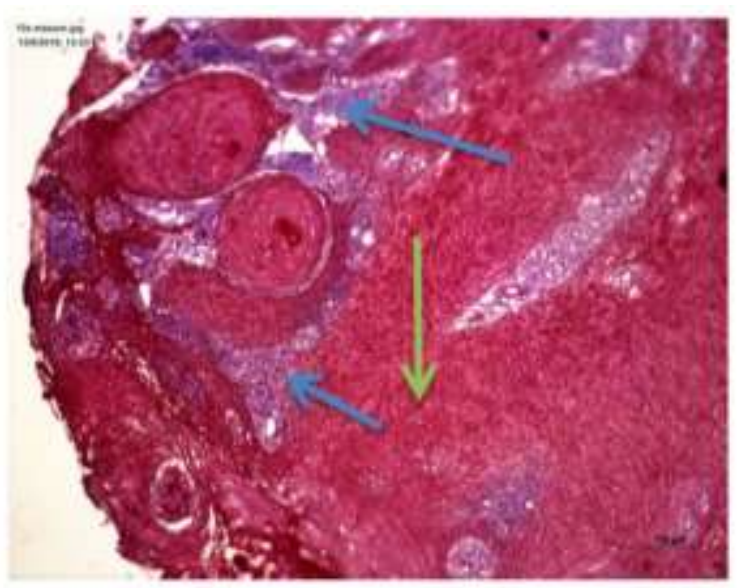

Fig: 4 Hyperkeratinsed cells taking reddish color (Green arrow), islands of neoplastic cells surrounded by blue stained collagen (Blue arrow). Masson Trichrome Stain $(100 \mathrm{x})$.

Intercellular bridging was observed (Fig 2). Neovascularization was also seen with in each islands of neoplastic cells (Fig 2), which resulted in bleeding. Those cells that were keratinizing showed dense pink cytoplasm with small hyper chromatic nuclei (Fig 3). Cells with keratinized cytoplasm without nuclei whorled together to form pink colored keratin pearls (Giri et al., 2011) (Fig 3). All the above features indicated a well differentiated tumor. On Masson trichrome staining, the hyper keratinized cells taken intense red color, each islands of neoplastic cells were surrounded by collagen which taken blue color (Fig 4). Based on gross and histopathological examinations, the tumor mass was confirmed as well differentiated squamous cell carcinoma. The visible growth was removed by cauterization method. In bovine, skin and soft tissue tumors are more (50\%). A study conducted by (Shruthi et al., 2018) pointed that, among cattle tumors squamous cell carcinoma consisted around 17. 54\%. (Ali, 1976) stated that among the report of 6000 horn cancer cases, 93\% cases were observed in working bullock. Udharwar et al., 2008 studied about the incidence, predisposing factors of horn cancer in bovine and recorded that, higher incidence may be attributed by the stress in aged animal, with higher incidence in males (66.66). This case report supports the occurrence of horn cancer in bullock less than 5 years of age.

\section{References}

1) Ali, 1976. Horn cancer in cattle in Iraq. Veterinary Pathology 13:453-454.

2) Giri DK, Kashyap DK, Dewangan G, Tiwari SK, Ghosh RC, Sinha B, 2011. Squamous cell carcinoma of horn and its surgical management - a report of three cases. International Journal of Livestock Research 1: 55-58.

3) Joshi BP, Soni PB, Ferar DT, Ghodasara DJ, Prajapati KS, 2009. Epidemiological and pathological aspects of horn cancer in cattle of Gujarat. Indian Journal of Field Vet 5: 15-18.

4) Luna LG, 1968. Manual of histologic staining methods of armed forces institute of pathology, 3rd Ed., Mc Graw Hill Book Company, New York.

5) Nivsarkar AE, Vij PK, Tantia MS, 2000. Animal Genetic Resources of India Cattle and Buffalo, Indian Council of Agricultural Research (ICAR), New Delhi: 64-67

6) Shruthi PJ, Sujatha K, Srilatha CH, Rayulu VC, 2018. Incidence of different tumors in Bovine. Open access journal of science 4: 220- 222.

7) Somvanshi R, 1991. Horn cancer in Indian cattle. Veterinary Bulletin 61: 901-10.

8) Udharwar SV, Aher VD, Yadav GU, Bhikane AU, B.P.Dandge, 2008. Study on Incidence, Predisposing factors, Symptomatology and Treatment of Horn cancer in Bovine with special reference to Surgery and Chemotherapy. Veterinary World 1: 7-9.

9) Vara PrasadMurthy RVS, Nasreen A, Naik SH, Sujatha K, Srilatha CH, 2016. Squamous cell carcinoma in Zebu cattle- a report of two cases. International Journal of Food, Agriculture and Veterinary Sciences 6: 11-14. 